UDK 347.921.2:347.96

https://doi.org/10.18485/union_pf_ccr.2021.ch11

MJur (Oxon) Selma Mezetović Međić, MA iur.*

\title{
AKTIVNA LEGITIMACIJA U POSTUPCIMA KOLEKTIVNE ZAŠTITE - IMA LI MJESTA ZA ADVOKATE?
}

\begin{abstract}
Apstrakt: Pitanje aktivne legitimacije u postupcima kolektivne zaštite je pitanje najvećeg razilaženja izmedu kontinentalnih $i$ common law pravnih sistema. Istovremeno, to je pitanje koje je gotovo u potpunosti ujedinilo evropske pravnike u stavu da se postupci kolektivne zaštite u Evropskoj uniji ne smiju povjeriti advokatima kao što je slučaj u Sjedinjenim Američkim Državama. Ovim se radom nastoji dati kritički osvrt na pitanje da li bi trebalo da advokati imaju ikakvu ulogu u postupcima kolektivne pravne zaštite. U tom cilju će prvo biti izloženi potencijalni izazovi u radu kvalifikovanih subjekata, prvenstveno kada su u pitanju njihovi kapaciteti, motivacija i finansijski resursi. Oni će biti dovedeni u vezu sa kompenzatornom i preventivnom ulogom kolektivne zaštite, te sa pitanjem navodne međusobne isključivosti rada usmjerenog na ostvarivanje profita i rada za javni interes. Autorica sugerira preispitivanje trenutnog isključivog i negativnog odnosa prema advokatima u svjetlu glavne svrhe kolektivne zaštite, a to je uspostavljanje snažnog, efikasnog i učinkovitog sistema izvršenja prava.
\end{abstract}

Ključne riječi: pravosuđe, kolektivna pravna sredstva, kvalificirani subjekti, zaštita potrošača, privatni advokat, zloupotreba sudskog postupka, minimalna harmonizacija.

\section{UVOD}

Postupci kolektivne zaštite omogućavaju da više oštećenih subjekata zaštitu povrijeđenih prava ostvare u jednom zajedničkom postupku. Načelno bi pravni poredak kroz postupke kolektivne zaštite trebalo da omogući onima čija su prava povrijeđena da ostvare svoje pravo uz maksimalnu uštedu vremena i novca, a koji inače od zaštite, na koju imaju pravo, odustaju jer su im postupci preskupi, jer nemaju vremena, jer ne poznaju pravo, jer su nepovjerljivi ili zbog sličnih razloga. Trebalo bi da postupci kolektivne zaštite pored potrošačima budu od koristi i pravosuđu jer bi omogućili jedan postupak, iako obiman, umjesto onoliko pojedinačnih postupaka koliko je povrijeđenih lica, odnosno pojedinih nastalih šteta.

Viša asistentkinja Pravnog fakulteta Univerziteta u Sarajevu e-mail: s.mezetovic@pfsa.unsa.ba 
Osnaživanje potrošača je jedan od ključnih izazova, ali i ciljeva u radu Evropske komisije, a što je potvrđeno i u studiji objavljenoj u januaru 2016. godine. ${ }^{1}$ Ovo nije prvo spominjanje osnaženog potrošača, nego samo dodatna potvrda pravca djelovanja koji je već više puta definiran kao i razvoj potrošačke politike. ${ }^{2}$ Program zaštite potrošača Evropske unije 2014-2020. ima za cilj da ojača zaštitu potrošača, naročito u segmentu izvršenja prava, i da poboljša pristup jednostavnim, efikasnim, brzim i jeftinim sredstvima zaštite, uključujući i alternativno rješavanje sporova. ${ }^{3}$ Evropska unija je prepoznala da, ukoliko želi imati funkcionirajuće unutrašnje tržište, mora imati potrošače voljne da na tom tržištu učestvuju, a samim tim ga pokreću i doprinose njegovom razvoju. Volja potrošača za učešćem na tržištu je između ostalog determinirana obimom i dostupnošću njihovih prava, te mogućnošću da svoja prava prinudno ostvare ako odnosi u koje su stupili poprime neželjeni tok. Kada su im prava poznata i lako ostvariva, veća je vjerovatnoća da će se potrošači češće i jednostavnije upuštati u nove transakcije. ${ }^{4}$ To će doprinijeti i generalnom osjećaju povjerenja u pravni promet, te unapređenju pravne izvjesnosti i sigurnosti, a samim tim i potvrditi opredjeljenje Unije da bude Evropa njenih građana.

Upravo motivirana razvojem konkurentnog tržišta, za koje su pretpostavka angažirani i povjerljivi potrošači, Evropska unija je posljednjih nekoliko godina odlučila intervenirati i u oblasti ostvarivanja prava, te omogućiti potrošačima realizaciju njihovih prava nastojeći da se izbjegnu dugotrajni i skupi sudski procesi. ${ }^{5}$ Tako je donesen niz pravnih akata, kako obavezujućih tako i neobavezujućih (preporuke, saopćenja), a najznačajniji su: Direktiva 2008/52/EU od 21. 5. 2008. o nekim aspektima mirenja u građanskim i trgovačkim stvarima, Direktiva 2009/22/EU od 23. 4. 2009 o tužbama za propuštanje kojima se štite potrošači, Direktiva 2013/11/EU o alternativnom rješavanju potrošačkih sporova (dalje u tekstu i: ARS Direktiva), Uredba 524/2013 od 21. 5. 2013. o online rješavanju potrošačkih sporova (dalje u tekstu i: ORS Uredba), Direktiva 2014/104/EU o štetama

1 Posebnu zahvalnost dugujem profesoru Issacharoff Samuelu za diskusije o ovoj temi.

London Economics, VVA Consulting i Ipsos Mori consortium, "Consumer vulnerability across key markets in the European Union”, Evropska komisija, januar 2016, p. 22, (http:// ec.europa.eu/consumers/consumer_evidence/market_studies/docs/vulnerable_consumers_ approved_27_01_2016_en.pdf).

2 Strategija "Europe 2020, a strategy for smart, sustainable and inclusive growth" COM (2010) 2020 final, p. 6. i p. 20, (http://eur-lex.europa.eu/legalcontent/EN/TXT/PDF/?uri=CELEX:52 010DC2020\&from=en, pristupljeno 3. 10. 2020).

3 Regulation (Eu) No 254/2014 of the European Parliament and of the Council of 26 February 2014 on a multiannual consumer programme for the years 2014-20 and repealing Decision No 1926/2006/EC. član 3. stav 1. tačka (c), (http://eur-lex.europa.eu/LexUriServ/LexUriServ. do?uri=OJ:L:2014:084:0042:0056:EN:PDF, 3. 10. 2020).

4 Povlakić, M., Mezetović Međić, S., 2016, Kolektivna zaštita (potrošača) prema pravu Evropske unije i pravu Bosne i Hercegovine, Aktualnosti građanskog i trgovačkog zakonodavstva i pravne prakse, 14, str. 247-248.

5 Davies, J. 2012, How Well Placed Is the Optimism Surrounding the New ADR/ODR Proposals?, Zeitschrift für Europäisches Unternehmens- und Verbraucherrecht 2, p. 63. Vidjeti i u: Jeretina, U., Uzelac, A., 2014, Alternative Dispute Resoultion for Consumer Cases: Are Divergences an Obstacle to Effective Access to Justice?, Mednarodna revija za javno upravo, XII (4), p. 43. 
za povredu prava konkurencije od 17. 4. 2014, te Provedbena uredba Komisije 2015/1051 od 1. 7. 2015. godine o načinima korištenja funkcijama platforme za online rješavanje sporova, načinima za podnošenje elektronskog obrasca za pritužbe, te načinima saradnje među kontaktnim tačkama predviđenim u Uredbi (EU) br. 524/2013 Evropskog parlamenta i Vijeća o online rješavanju potrošačkih sporova. Na navedenu listu svakako treba dodati i Preporuku 2013/396/EU od 11. 6. 2013. o zajedničkim načelima za kolektivne tužbe na propuštanje i tužbe radi naknade štete u državama članicama kod povrede prava zajamčenih zakonodavstvom Unije, te Saopćenje prema Evropskom horizontalnom okviru za kolektivne mehanizme zaštite $\operatorname{COM(2013)~} 401$ final. Iako se radi samo o preporuci, ipak je za države članice predviđena obaveza usklađivanja svog prava na način da usvoje principe sadržane u ovom dokumentu, kao i da podnose odgovarajuće izvještaje Evropskoj komisiji.

Međutim, navedene zakonodavne aktivnosti nisu dale značajniji rezultat. Sve se ponovo aktiviralo tek nakon što se desilo masovno otkazivanje Ryanair letova u 2017. godini, ${ }^{6}$ te velika prevara počinjena od strane Volkswagena, poznata i kao Dieselgate afera. Odnosno, radi veće preciznosti, nije se desilo čak ni u tom momentu, nego onda kada su potrošači koji su pretrpjeli identičnu štetu u Sjedinjenim Američkim Državama tu štetu naplatili, dok potrošači u Evropskoj uniji nisu ostvarili nikakva prava. Postao je očigledan jaz u ostvarivanju prava koji je ukazao na to da ostvarivanje prava zavisi od mjesta gdje potrošači žive. Tako od ukupno 11 miliona potrošača koji su kupili Volkswagen automobil sa prevarnim softverom, njih 8,5 živi na području Evropske unije. Oko 600.000 je iz Sjedinjenih Američkih Država, dok su ostalih 1,6 miliona kupci iz drugih država. Prema izvještajima iz decembra 2018. godine, Volkswagen, koji je stavljao $\mathrm{u}$ promet sporna vozila, uspio je gotovo u potpunosti riješiti problem na američkom tržištu. Dio oštećenih vlasnika vozila je odlučio da dobije ugrađene nedostajuće filtere. Uz to su u prosjeku dobili i po 10.000 dolara naknade. Vozači koji su vratili vozila dobili su u prosjeku po 40.000 dolara. ${ }^{7}$ U Australiji je VW također pristao na nagodbu i platit će ukupno 127 miliona australskih dolara kao kompenzaciju vlasnicima. Potrošači u Evropskoj uniji još uvijek nisu dobili ništa, ${ }^{8}$ iako ih je oštećenih skoro četrnaest puta više. ${ }^{9}$ Razlog zašto su štete dosu-

6 Letovi su otkazani za više od 400.000 putnika zbog greške kompanije Ryanair. Više na: https://www.theguardian.com/business/2017/sep/18/ryanair-flight-cancellation-passengersholiday i https://www.bbc.com/news/business-41311603, 21. 10. 2020.

7 https://www.handelsblatt.com/today/companies/dieselgate-volkswagen-diesel-ownerswin-in-the-us-but-go-empty-handed-in-germany/23835792.html?ticket=ST-397482gRc7Bbtdbw6rE7Dgg7vn-ap6, 20. 10. 2020.

8 U Njemačkoj je u novembru 2018. godine uvedena tzv. Musterfeststellungsklage koja omogućava kolektivnu zaštitu, ali sa ograničenim dejstvom. Ona kao rezultat može dati samo presudu kojom se utvrđuje da je do povrede došlo i da Volkswagen mora nadoknaditi štetu, a povrijeđeni potrošači bi tek na osnovu toga mogli pokretati novi postupak za individualno utvrđivanje štete čija se naknada može potraživati. Prvi postupci po osnovu ovog zakona, a u vezi sa Dieselgate aferom, su u toku, (https://www.euractiv.com/section/transport/news/firstdieselgate-ruling-by-germanys-top-court-set-to-flag-legal-clarity/20. 10. 2020).

9 https://www.handelsblatt.com/today/companies/dieselgate-volkswagen-diesel-ownerswin-in-the-us-but-go-empty-handed-in-germany/23835792.html?ticket=ST-397482gRc7Bbtdbw6rE7Dgg7vn-ap6, 20. 10. 2020. 
đene i/ili naplaćene u Americi i Australiji, a u EU nisu, nije broj i iznos ukupne štete. Razlog je pravni sistem, i to razlika u načinu funkcioniranja i ostvarivanja kolektivne zaštite. Iako u određenim državama Evropske unije nacionalni pravni sistemi predviđaju postojanje kolektivne zaštite, ona se ne primjenjuje u praksi ili barem ne u dovoljnoj mjeri. Čak i u državama u kojima postoje određeni mehanizmi ostvarivanja kolektivne zaštite, to ne garantuje potrošačima da će njihovo pravo zaista biti ostvareno, odnosno zaštićeno.

Upravo navedena razlika u tretmanu američkih i evropskih potrošača je ukazala na nepostojanje adekvatnog mehanizma zaštite, ali isto tako i na nepravedan tretman potrošača iz Evropske unije koji su pretrpjeli potpuno identičnu štetu, počinjenu na isti način od istog privrednika, ali koji su onemogućeni dobiti adekvatnu naknadu samo iz razloga što žive u drugoj državi. Da bi u ovakvom i sličnim slučajevima spriječila neosnovano bogaćenje privrednika koji postupaju protupravno, te s druge strane bespravno nanošenje štete potrošačima, Evropska unija je poduzela mjere u pravcu uvođenja jednog postupka koji će postojati u svim državama članicama, ne dirajući time u već postojeće postupke i vidove zaštite u nacionalnim pravnim porecima. Ovakav razvoj događaja je dao dugo čekani podsticaj u pravcu razvijanja evropskog pravnog okvira kolektivne pravne zaštite, a što je dovelo do intenziviranja aktivnosti u pravcu usvajanja novog instrumenta i u konačnici do usvajanja teksta Prijedloga Direktive o udružnim tužbama za zaštitu kolektivnih interesa potrošača i stavljanju izvan snage Direktive 2009/22/EZ. ${ }^{10}$

Ovaj razvoj situacije je generalno dočekan pozitivno, ${ }^{11}$ jer se smatra da je evropski zakonodavac pronašao način da pruži adekvatnu zaštitu, te da tu zaštitu izbalansira sa interesima država članica na način da ne dira u njihove nacionalne pravne sisteme. Pri tome adekvatna pravna zaštita podrazumijeva i izvršenje jer sâm garant materijalnog prava ne znači previše ako ono nije lako provodivo. Vid kolektivne zaštite predviđen Prijedlogom Direktive treba da bude dopuna već postojećeg načina zaštite ili da bude vodič kako da zemlje članice uspostave mehanizam ostvarivanja kolektivne zaštite uz uvažavanje nacionalnih pravnih tradicija. U svakom slučaju Direktiva ne sprečava države članice da zadrže svoj postojeći okvir niti ih obvezuje da ga izmijene, ali su dužne obezbijediti minimum zaštite koji Direktiva predviđa. Države članice imat će mogućnost provoditi pravila predviđena ovom direktivom u svoj sistem kolektivne pravne zaštite ili ih provoditi u posebnom postupku. S obzirom na to da se radi o direktivi minimalne harmonizacije, ${ }^{12}$ može se reći da se njome postavljaju temelji, a zemlje članice su svakako slobodne pružiti i viši nivo zaštite ukoliko to smatraju potrebnim. ${ }^{13}$

10 Prijedlog Direktive o udružnim tužbama za zaštitu kolektivnih interesa potrošača i stavljanju izvan snage Direktive 2009/22/EZ COM(2018) 184 final od 11. 4. 2018. Dalje u tekstu i: Prijedlog Direktive.

11 „Evropski potrošači stekli su moćno novo pravo da traže pravnu zaštitu protiv kompanija.“ Više na: https://www.politico.eu/article/europes-landmark-deal-on-collective-redress-explained/, 21. 10. 2020.

12 Tačka 4a. Preambule prečišćenog teksta Prijedloga Direktive.

13 Za analizu prednosti minimalne harmonizacije vidjeti: Weatherill, S., 2012, Maximum versus Minimum Harmonization: Choosing between Unity and Diversity in the Search for the Soul 
Ipak, ostaje pitanje koliko će navedeno zaista djelovati u praksi. Naravno, kao i sa svakim novim pravnim aktom, vrijeme i iskustvo uvijek pokazuju uspješnost. Međutim, u ovom su slučaju neki nedostaci već uočljivi. Smatramo da će pitanje aktivne legitimacije biti presudno za uspjeh kolektivne zaštite, odnosno ostvarivanje cilja koji je Evropska unija zacrtala, a to je uspostavljanje čvrstog, učinkovitog i djelotvornog sistema izvršenja prava. ${ }^{14}$

\section{AKTIVNA LEGITIMACIJA U POSTUPCIMA KOLEKTIVNE ZAŠTITE PO MJERI EVROPSKOG ZAKONODAVCA}

Ovlaštenje za pokretanje postupka kolektivne zaštite je detaljno regulirano Prijedlogom Direktive, koji je trenutno u zakonodavnoj proceduri, ali nije donijelo nikakve novosti u smislu principijelnog opredjeljenja na nivou Evropske unije u pogledu aktivne legitimacije. Stav evropskog zakonodavca je ostao čvrsto na stanovištu da su jedini ovlašteni podnosioci zahtjeva za kolektivnu zaštitu kvalificirani subjekti. Prijedlog Direktive donosi niz kriterija koje takvi subjekti moraju ispuniti da bi zaista bili kvalificirani, pa tako predviđa punu transparentnost u pogledu osnivačke strukture i osnivačkih akata, a naročito u pogledu načina i izvora finansiranja rada tih tijela. Pored toga sam Prijedlog Direktive predviđa da kvalificirani subjekti moraju biti zakonito osnovani u skladu sa pravom države članice, imati legitiman interes za osiguravanje poštovanja prava Unije obuhvaćenog Prijedlogom Direktive, imati neprofitni karakter, uspostavljene interne postupke za sprečavanje sukoba interesa između sebe i svojih ulagača, te biti nezavisni u svom djelovanju od tržišnih subjekata. ${ }^{15}$

Inače je pitanje aktivne legitimacije u postupcima kolektivne zaštite pitanje po osnovu kojeg je došlo do najvećeg razilaženja između kontinentalnih i anglosaksonskih pravnih sistema. U isto vrijeme, ovo je pitanje povodom kojeg su se gotovo u potpunosti ujedinili evropski pravnici sa stavom da postupci kolektivne zaštite u Evropskoj uniji ne mogu biti povjereni privatnim advokatima, ${ }^{16}$ a što je praksa u Sjedinjenim Američkim Državama. ${ }^{17}$ Još od samih početa-

of the Internal Market, From Single Market to Economic Union: Essays in Memory of John A. Usher, pp. 175-199.

14 Vidjeti Obrazloženje Prijedloga Direktive.

15 Član 4. Prijedloga Direktive.

16 Bilo je i drugačijih mišljenja, pa tako Taruffo smatra da je evropsko odbijanje bilo čega američkog u vezi sa kolektivnom zaštitom zapravo bazirano na neznanju. Vidjeti: Taruffo, M., 2001, Some remarks on group litigation in comparative perspective, Duke Journal of Comparative \& International Law, 11(2), p. 414.

17 Jedan od elemenata tzv. „toksičnog koktela“ iz američkog pravnog sistema koji se u Evropi obavezno mora izbjeći jeste i ovlaštenje advokata na pokretanje i vođenje postupka, kako ga je nazvao Hodges, C., 2014, Collective Redress: A Breakthrough or a Damp Sqibb?, Journal on Consumer Policy, 37, pp. 71-72. Vidjeti i: Green Paper On Consumer Collective Redress COM (2008) 794 final od 27. 11. 2008. godine, Rezoluciju Evropskog parlamenta „Towards a coherent European approach to collective redress" (2011/2089(INI)) od 2. 2. 2012, te Preporuku 2013/396/EU od 11. 6. 2013. o zajedničkim načelima za kolektivne tužbe na propuštanje i tužbe radi naknade štete u državama članicama kod povrede prava zajamčenih 
ka svih diskusija u vezi sa kolektivnom zaštitom bio je prisutan stav da se želi po svaku cijenu zaobići bilo šta u vezi sa kolektivnom zaštitom što bi moglo asocirati na američke class actions,${ }^{18}$ a sve u cilju izbjegavanja mana američkog sistema kolektivne zaštite. Te mane se prije svega ogledaju u mogućnosti zloupotrebe od strane privatnih advokata u smislu vođenja slučaja na način da se kreira izuzetan društveni pritisak uslijed kojeg optuženi pristaju na nagodbu samo kako bi izbjegli negativni publicitet, ${ }^{19}$ te mogućnost advokata da ostvare nesrazmjerno veliku zaradu s obzirom na to da naplaćuju određeni procenat od naplaćenog iznosa naknade štete. Ostvarenje tog profita se smatra motivom za vještačko kreiranje negativne reklame, te okupljanje što više ljudi kako bi imali što masovniju štetu, koja će nakon objave u medijima idealno voditi do naplate izuzetno visoke naknade štete.

Negativna reklama i medijska eksponiranost zasigurno mogu imati snažan utjecaj. U Sjedinjenim Američkim Državama su se u relativno kratkom vremenskom razmaku desila dva značajna slučaja koja su završila na postupcima class actions, a koja ilustrativno prikazuju dejstvo medija. U prvom slučaju se radilo o automobilima marke Toyota koji su imali navodnu grešku nenamjernog ubrzavanja kretanja bez želje vozača. Sve je počelo sa saobraćajnom nesrećom u kojoj je vozač pozvao 911, službu za hitne slučajeve, iz iznajmljenog auta marke Toyota koje se bez njegovog svjesnog utjecaja kretalo velikom brzinom i konstantno nastavljalo ubrzavati. U kratkom i vrlo dramatičnom pozivu je tvrdio da auto nema kočnica. Članovi porodice koji su bili s njim u autu su upozoravali da se približavaju kraju auto-puta. Poziv je naglo prekinut a uslijed sudara sa drugim autom, pri čemu su i vozač i tri člana porodice koji su bili u autu smrtno stradali. Nakon te nesreće američki mediji su prenosili vijest zajedno sa snimkom dramatičnog telefonskog poziva. ${ }^{20} \mathrm{~S}$ obzirom na interes i reakcije javnosti, stvoren je veliki pritisak koji je doveo do toga da bude proveden nadzor Nacionalne uprave za drumski saobraćaj, kao i da uprava Toyote bude saslušana u američkom Kongresu. Sve to je dovelo do podnošenja stotina tužbenih zahtjeva od strane vlasnika Toyota vozila koji su se pozivali na problem sa elektronskim sistemom za kontro-

zakonodavstvom Unije. U tekstu Prijedloga Direktive se u preambuli na više mjesta spominje izbjegavanje parnica koje bi mogle biti zloupotrijebljene, a isto je sadržano čak i u tekstu samog Prijedloga Direktive, u njegovom članu 1. koji regulira područje primjene.

18 Tzankova tvrdi da je i sam pojam class actions dobio negativnu konotaciju u Evropi uslijed opsežnog lobiranja poslovne zajednice. Vidjeti: Tzankova, I., 2016, Collective Redress in Vie d'Or: A Reflection on a European Cultural Phenomenon, Class Actions in Context, Edward Elgar Publishing, fn. 3, p. 118. Ono što se često, a ponekad i namjerno, zaboravlja jeste da class actions postoje u potpuno drugačijem pravnom sistemu u odnosu na evropske pravne sisteme. Stoga je važno naglašavati da uvođenje kolektivne zaštite ne znači preuzimanje svih tekovina američkog class actions sistema. Više kod: Voet, S., 2014, European Collective Redress: A Status Quaestionis, International Journal of Procedural Law, 4, p. 101.

19 Prilikom diskusija koje su prethodile usvajanju Preporuke 2013/396/EU protiv uvođenja mogućnosti da privatni advokati zastupaju u postupcima kolektivne zaštite bili su privredni subjekti. Zanimliivo za primijetiti, ali nimalo iznenađujuće. Udruženja potrošača se nisu očitovala.

20 Vidjeti npr. https://www.nytimes.com/2010/02/01/business/01toyota.html, https://www.latimes.com/archives/la-xpm-2009-oct-25-na-toyota-crash25-story.html, https://www.autoblog. com/2009/12/10/toyota-tragedy-saylor-family/, 5. 10. 2020. 
lu gasa, odnosno ubrzanja, te pokretanja postupka kolektivne zaštite. Međutim, stručne kontrole su pokazale da ne postoji nikakav problem sa Toyota vozilima. A također je utvrđeno da je uzrok tragične nesreće od koje je sve počelo zapravo bila podloga ispod nogu vozača koja se zakačila za papučicu za dodavanje gasa u automobilu. Sama podloga nije bila original Toyota, nego ju je postavila agencija za iznajmljivanje auta. Unatoč tome ipak je sve okončano nagodbom većom od milijardu dolara između Toyote i vlasnika Toyota automobila koji su željeli nadoknaditi gubitke zbog smanjene vrijednosti vozila uslijed rizika od nenamjernog ubrzanja. ${ }^{21}$ Ipak, iako nesreća koja je bila uzročnik masovnog postupka nije bila uzrokovana greškom na samom automobilu, cijeli slučaj je doprinio pojačanom nadzoru američke Nacionalne uprave za drumski saobraćaj, a što je u konačnici dovelo do poboljšanih sigurnosnih karakteristika Toyotinih vozila.

Nešto manje od godinu dana poslije desila se nesreća koja će biti uzrok drugog slučaja masovne parnice. Naime, podmorsko crpilište nafte British Petroleum (BP) je eksplodiralo u Meksičkom zaljevu, a prije nego što je bušotina trajno zatvorena, gotovo pet miliona barela nafte je izliveno $\mathrm{u}$ vode pored američke zaljevske obale prijeteći ekološkom katastrofom ogromnih razmjera. Poginulo je 11 radnika BP-a, njih 17 ih je povrijeđeno, dok su ribarstvo i turizam, od kojih je to područje živjelo, preko noći ugašeni. Mediji u Sjedinjenim Američkim Državama posvetili su se opširnom izvještavanju koje je uključivalo i direktan televizijski prijenos izlijevanja nafte u okean, sve dok bušotina konačno nije začepljena. Ovakva pažnja medija stvorila je ogroman politički pritisak koji je rezultirao presedanom da tadašnji predsjednik SAD Barack Obama lično učestvuje u pregovorima o sporazumu za oštećene sa štetnikom British Petroleum, odnosno formiranju fonda za potraživanja u iznosu od 20 milijardi dolara kojim će biti upravljano neovisno i neutralno. ${ }^{22}$ Oštećeni su se mogli odlučiti za fond i namiriti svoja potraživanja direktno iz tog fonda, ali su isto tako mogli podnijeti zahtjev za sudskim odlučivanjem. Medijska pokrivenost i brzo širenje informacija su doveli ne samo do velikog pritiska javnosti i informisanosti oštećenih o mogućnostima koje su im na raspolaganju, nego i do podnošenja, a potom i ispitivanja radi mogućeg procesuiranja, hiljada potencijalno lažnih zahtjeva za naknadu. ${ }^{23}$

Iz navedena dva slučaja nedvojbeno je da je utjecaj medija izuzetan. Iz današnje perspektive, kada je digitalizacija postala naša svakodnevica, sve poprima i puno veće razmjere imajući u vidu da su se oba događaja desila prije deset godina. Danas širenje informacija zahvaljujući internetu i društvenim mrežama posebno više ne poznaje ni teritorijalne, ni vremenske, a ni jezičke granice. Prednosti medijskog pritiska jesu upravo u tome što se veoma brzo šire informacije, pa na taj način veliki broj ljudi može saznati i pridružiti se postupku kolektivne zaštite, ali to istovremeno znači i povećan broj tužitelja koji vide priliku za brzu

21 Vidjeti: Stier, B., 2016, The Promise and Peril of Media and Culture: The Toyota unintended acceleration litigation and the Gulf Coast Claims Facility in the United States, Class Actions in Context, Edward Elgar Publishing, pp. 93-115; Stier, B., Tzankova, I., 2016, The Culture of Collective Litigation: A Comparative Analysis, Class Actions in Context, Edward Elgar Publishing, pp. 23-50.

22 https://edition.cnn.com/2010/US/06/16/obama.bp.escrow/index.html, 5. 10. 2020.

23 Vidjeti: Stier, B., 2016; Stier, B., Tzankova, I., 2016. 
zaradu i zloupotrebu, a samim tim i povećanu potrebu za posebnim provjeravanjem takvih zahtjeva u već preopterećenom postupku. ${ }^{24}$

Ipak, kada navedeno posmatramo iz perspektive razvoja kolektivne zaštite u Evropskoj uniji, ne treba zanemariti činjenicu da se radi o različitoj kulturi, ${ }^{25}$ kao i da je efikasnost kolektivne zaštite, koja je bazirana i na velikom odzivu oštećenih u Sjedinjenim Američkim Državama, rezultat dubokog nepovjerenja u javno izvršenje. ${ }^{26}$ Nasuprot tome je Evropska unija čiji stanovnici, zahvaljujući drugačijem društvenopolitičkom uređenju, ali i historijatu istog, ipak vjeruju državi i oslanjaju se na tu društvenu tvorevinu. Samim tim se ne može očekivati da se kreiranje negativnog publiciteta, koje rezultira u postizanju nagodbi velikih novčanih vrijednosti, po automatizmu preslika sa identičnim posljedicama i na prostoru Evropske unije.

\section{KVALIFICIRANI PREDSTAVNIČKI SUBJEKTI KAO OPTIMALNO RJEŠENJE?}

Jasne su i razumljive negativne strane koje se žele izbjeći onemogućavanjem privatnih advokata da učestvuju u postupku, međutim čini se da se dosta jednostrano posmatra uloga zastupnika tužilaca u ovim postupcima. Iako mogu doprinijeti stvaranju velikog društvenog i medijskog pritiska, oni ipak teško mogu $\mathrm{u}$ tome uspjeti tamo gdje je privrednik postupao potpuno u skladu sa pravom. Ako je ipak radio protupravno, za svoje postupanje treba da odgovara, jer se u suprotnom onemogućava samoreguliranje tržišta. Osim toga, ne znači ni da je privrednik oštećen trajno ako se vođenje postupka povjeri privatnim advokatima. ${ }^{27}$ Naravno da ta odgovornost treba biti srazmjerna počinjenoj šteti, te služiti kolektivnim interesima i biti usmjerena javnoj svrsi, ali se postavlja pitanje da li je jedini način, a posebno da li je najefikasniji, povjeravanje isključivo kvalificiranim predstavničkim subjektima.

Nekoliko je segmenata koji će u narednim redovima biti oslovljeni kako bi se analizirala isključiva opredijeljenost za kvalificirane subjekte kao jedine ovlaštene podnosioce zahtjeva za postupke kolektivne zaštite. $S$ tim u vezi će biti adresirani (i) mogući izazovi za rad kvalificiranih subjekata, te će (ii) kroz prizmu ostvarivanja prava na pristup sudu, što je vodilja Evropske unije u zakono-

24 Stier, B., 2016, p. 113.

25 O razvoju tzv. „kompenzatorne kulture“ koja podstiče ljude da podnose zahtjeve za stvarne ili navodne nesreće, bez obzira na uzročno-posljedičnu vezu ili stvarno postojanje odgovornosti kod Hodges, C., 2001, Multi-Party Actions: European Approach, Duke Journal of Comparative \& International Law, 11(2), p. 339. O poređenju različitih sistema u kojima se, s jedne strane, država smatra bizarnom tvorevinom u koju se nema povjerenja, pa je fokus na privatnom izvršenju i, s druge strane, onih u kojima je država zaštitnica i na nju se oslanja više kod: Issacharoff, S., 2017, Collective Action and Class Action, pp. 1-19.

26 Uzelac, A., 2014, Why No Class Actions in Europe? A View from the Side of Dysfunctional Justice Systems, Multi-Party Redress Mechanisms in Europe: Squeking Mice?, p. 68.

27 Prodaja Volkswagenovih automobila u 2018. godini u Americi ponovo bilježi rast unatoč skandalu Dieselgate, (https://www.dw.com/en/volkswagen-bmw-increased-us-car-sales-in2018/a-46954696, 6. 10. 2020) 
davnim aktivnostima u ovoj oblasti, biti dat osvrt na ulogu, odnosno potencijal kolektivne zaštite, te međusobnu isključivost rada orijentiranog na profit i ostvarivanja javnog interesa.

\subsection{MOGUĆI IZAZOVI U RADU KVALIFICIRANIH SUBJEKATA}

U vezi sa kvalificiranim subjektima se prije svega postavlja pitanje njihovog kapaciteta za vođenje postupaka kolektivne zaštite, njihove profesionalne i lične motivacije, te postojanje finansijskih resursa koji će omogućiti vođenje postupka, ali koji će isto tako garantovati poštovanje principa da gubitnik plaća troškove postupka. ${ }^{28} \mathrm{U}$ nastavku će biti izloženi odvojeno iako su u suštini isprepleteni i međusobno zavisni.

\subsubsection{Kapacitet kvalificiranih subjekata za vođenje postupaka kolektivne zaštite}

Prvo sporno pitanje je pitanje kapaciteta. Preporuka o zajedničkim načelima postupaka kolektivne zaštite iz 2013. godine predviđa da kvalificirani subjekti, pored ostalih uslova koje moraju ispuniti, moraju imati dovoljno kapaciteta u smislu finansijskih i ljudskih resursa i pravničke ekspertize da zastupaju više tužilaca u njihovom najboljem interesu. ${ }^{29}$ Međutim, aktuelni Prijedlog Direktive ne sadrži ovakvu odredbu, nego kao uslove postavlja samo to da se radi o pravnoj osobi koja ima najmanje godinu dana javnih aktivnosti u polju zaštite potrošača, čija svrha osnivanja opravdava legitiman interes zaštite potrošača i koja je neprofitnog karaktera. ${ }^{30}$ Posljedice koje bi nastupile ako bi kvalifikovani subjekt izgubio svoj imenovani status u toku trajanja parnice nisu jasne. ${ }^{31}$ Državama članicama je prepušten izbor subjekata koji mogu biti ovlašteni na pokretanje postupka kolektivne zaštite, vrste postupka i obima angažmana. Kod većine država članica kriteriji koji jesu uspostavljeni su podudarni sa onima koje predviđa Prijedlog Direktive, te se uglavnom odnose samo na postojanje legitimnog interesa za zastupanje i neprofitni karakter kvalificiranih subjekata. ${ }^{32}$

28 Evropski zakonodavac se odlučio za prihvatanje ovog principa u članu 8a Prijedloga Direktive kao garanta da neće doći do zloupotrebe postupaka kolektivne zaštite od strane potrošača, a na štetu privrednika, odnosno kao svojevrsnog balansa između ostvarivanja prava na pristup sudu i zaštite privrednika. Pojedini autori smatraju da će sama primjena ovog principa dovesti do nepravde, a što je potvrđeno i od strane Evropskog suda za ljudska prava koji tvrdi da dosuđivanje troškova koji su prekomjerni može odvratiti evropske građane od ostvarivanja njihovih osnovnih prava. Više kod: Smith, V., 2011, Towards a Coherent European Approach to Collective Redress: More Questions than Answers, Business Law Review, 32, p. 208.

29 Tačka 4. c) Preporuke. Preporuka također predviđa u tački 5. i da će kvalificirani subjekt izgubiti svoj status ako bilo koji od navedenih uslova vremenom prestane biti ispunjen.

30 Član 4. stav 3. Prijedloga Direktive.

31 Poretti, P., 2010, Collective Redress in the European Union - Current Issues and Future Outlook, EU and Comparative Law Issues and Challenges Series, 3, p. 345.

32 Poretti, P., 2010, p. 343. 
Jasno je da je u Evropskoj uniji očigledno nepovjerenje prema tzv. pravničkom poduzetništvu kao pokretačkoj snazi koja stoji iza kolektivnih tužbi u Sjedinjenim Američkim Državama. Međutim, postavlja se pitanje koji će mehanizmi biti najpogodniji ako Evropska unija za svoje građane želi efikasno privatno izvršenje i njegove pozitivne posljedice za zaštitu potrošača, jer sama činjenica da postoje sudovi i udruženja ne znači automatski da će imati kapacitet da rade u ovakvim slučajevima. ${ }^{33} \mathrm{U}$ vezi sa trenutnim opredjeljenjem evropskog zakonodavca povodom aktivne legitimacije nekoliko je problematičnih pitanja koja se javljaju. Naime, upitno je koliko je moguće zamisliti organizaciju za zaštitu potrošača koja će moći kadrovski i organizacijski podnijeti da jednako kvalitetno zastupa sve oštećene u nekoliko istovremenih postupaka za kolektivnu zaštitu. A teoretski se može desiti da je u isto vrijeme aktivno nekoliko slučajeva sličnih npr. Dieselgate-u, naravno povodom drugih povreda, ali sa više stotina ili hiljada oštećenih po slučaju. Nemoguće je predvidjeti broj slučajeva, ali i broj oštećenih, kao i vremenske okvire. S druge strane, ako nema aktivnih slučajeva kolektivne zaštite, problematičnim se može pojaviti opravdavanje broja zaposlenih, a koji moraju biti zaposleni, odnosno u pripravnosti, ako bi se pojavila kolektivna šteta i potrošači kojima treba zaštita u takvom postupku. Potom se postavlja pitanje kriterija za odabir za zastupanje ako zbog kapaciteta ovlaštenog pokretača postupka ne bude moguće sve oštećene zastupati istovremeno. $\mathrm{Da}$ li će u tom slučaju potrošači čija su prava povrijeđena nešto kasnije čekati da dođu na red kod kvalificiranog subjekta, jer zaposleni ne mogu podnijeti ni kvalifikacijski niti vremenski nekoliko istovremenih komplikovanih parnica sa stotinama ili hiljadama oštećenih? Ili će masovnost povrede biti presudna? I kako će ovo biti kompatibilno sa ekspeditivnošću postupka, koju su države članice dužne garantovati, ${ }^{34}$ a koja bi trebalo da spriječi dalju štetu koja može biti prouzročena praksom privrednika koja je predmet udružne tužbe? Mogućnost formiranja ad hoc kvalificiranih subjekata je samo djelimični odgovor, jer povlači za sobom ista pitanja koja se postavljaju i u vezi sa stalnim subjektima.

Sljedeći izazov za kvalificirane subjekte su motivacija i lični interes zastupnika koji su angažirani na određenom slučaju kolektivne zaštite unutar kvalificiranog subjekta. Lični interes u postupcima kolektivne zaštite je uglavnom finansijske prirode. Ako zastupnik nema taj motiv, motiv za uspjehom u sporu se vrlo lako može izjednačiti sa motivom tog kvalificiranog tijela, dok pitanje lične posvećenosti, a samim tim i pravničke domišljatosti i kreativnosti, može pasti u drugi plan. Ideološki podsticaji, odnosno efikasna pravna zaštita zasnovana na njima, dugoročno su neodrživi i malo je vjerovatno da se tako radi sa posvećenošću koju postupci kolektivne zaštite zahtijevaju. ${ }^{35}$

33 Issacharoff, S., Samuel, I., The Institutional Dimension of Consumer Protection, u: Cafaggi, F., Micklitz, H.-W. (eds.), 2009, New Frontiers of Consumer Protection: The Interplay between Private and Public Enforcement, p. 60.

34 Član 17. Prijedloga Direktive.

35 Stadler, A., Foreword, u: Lein, E., Fairgrieve, D., Otero Crespo, M., Smith, V. (eds.), 2015, Collective Redress in Europe: Why and How?, British Institute of International and Comparative Law; Tzankova, I., 2016, p. 130. 
Pored navedenog može se postaviti i pitanje legitimiteta evropske filozofije kolektivnog pravnog lijeka zasnovanog isključivo na udruženjima, odnosno adekvatnosti zastupanja imajući u vidu da će većina odluka, koje imaju veliki utjecaj na živote drugih, biti donesena od strane pojedinaca koji pri tome nisu izabrani od onih koje zastupaju. ${ }^{36}$

Nadalje, važno je napomenuti da uspjeh mehanizma kolektivne zaštite ne zavisi samo od tužilaca, odnosno ovlaštenih za pokretanje postupka, nego zavisi i od institucionalnog okvira u kojem će se postupak provoditi, te u konačnici ostvariti zaštita prava. Prema tome, uloga suda je i te kako značajna. Više studija slučaja u različitim pravnim sistemima je pokazalo da samo uvođenje postupka kolektivne zaštite nije dovoljno, jer svi postupci koji podrazumijevaju neki vid udruživanja tužbenih zahtjeva i općenito veliki broj pojedinačnih tužbi zahtijevaju značajne vještine vođenja slučajeva, zatim nesmetano digitalno funkcionisanje i sudova i zastupnika, te naročito proceduralni okvir koji dozvoljava sudijama fleksibilno upravljanje slučajevima uz saradnju sa zastupnicima stranaka u sporu. ${ }^{37}$ Autori sa European Law Institute-a su u svojoj Studiji o kolektivnoj zaštiti također istakli preporuku da države članice i Evropska unija uspostave programe obuke za sudije koji će se baviti postupcima kolektivne zaštite imajući na umu da se vođenje predmeta u masovnim sporovima razlikuje od vođenja uobičajenih parnica. ${ }^{38} \mathrm{~S}$ druge strane, ideja o fleksibilnosti sudija u postupku je suprotna strogoj prirodi procesnog zakonodavstva i dužnosti primjene jednakih pravila na svaki slučaj, a koja je svojstvena kontinentalnim pravnim sistemima. ${ }^{39}$

\subsubsection{Finansiranje kvalificiranih subjekata}

Kapacitet za pokretanje i vođenje postupka kolektivne zaštite zavisi i od postojanja finansijskih resursa. Finansiranje, pa tako i kapacitet za vođenje više desetina, stotina ili hiljada slučajeva u istom postupku, prema trenutnoj regulativi zavisiće od javnih sredstava. To praktično znači da budžet svake države članice treba pred-

36 Tzankova ističe da su „agencijski problemi“ koji se javljaju u sistemu kolektivne zaštite zasnovanom na udruženjima zapravo vrlo slični problemima prisutnim u sistemima potpuno privatne kolektivne zaštite gdje advokati vode postupke i ne nestaju samo zato što tužioci imaju drugačiju oznaku. „U svjetlu takvog nedostatka znanja, evropsko odobravanje uloge udruženja i fondacija ili 'imenovanih subjekata', kako je istaknuto u Evropskoj preporuci o kolektivnom pravnom lijeku u kolektivnim tužbama, u najmanju je ruku zapanjujuće." Vidjeti: Tzankova, I., 2016, pp. 131-132. Tako i: Issacharoff, S., 2017, p. 3. „Delegiranje kolektivnih ovlašćenja instituciji bez demokratskog pedigrea države zahtijeva neko opravdanje.“

37 Stadler, 2015, p. xvii.

38 Statement of the European Law Institute on Collective Redress and Competition Damages Claims, 2014, p. 25, (https://www.europeanlawinstitute.eu/fileadmin/user_upload/p_eli/ Publications/S-5-2014_Statement_on_Collective_Redress_and_Competition_Damages_Claims.pdf, 2. 10. 2020).

39 Uzelac komentarišući sudove u Jugoistočnoj Evropi tvrdi i da s obzirom na to da individualne parnice traju dugo vremena i neefikasne su, teško se može očekivati da bi postupci kolektivne zaštite mogli biti išta efikasniji. Detaljnije o ulozi sudova i generalnom skepticizmu da će se kolektivna zaštita ikada razviti u ozbiljan proceduralni mehanizam vidjeti kod: Uzelac, A., 2014. Einhaus također dovodi u pitanje kapacitet sudova. Vidjeti: Einhaus, S., 2008, Kollektiver Rechtsschutz im englischen und deutschen Zivilprozessrecht, p. 45. 
vidjeti iznos koji će pokriti troškove postupka, troškove rada kvalificiranog subjekta, moguće dodatne troškove, npr. vještačenja revizorskih kuća, ali isto tako znači da taj iznos nije niti može biti poznat unaprijed. Pored ove nepoznanice, neminovno se dalje nameće i pitanje da li su sve države Unije jednako sposobne u svojim budžetima predvidjeti dovoljno sredstava za funkcionalan rad ovih tijela, odnosno obezbijediti jednaku zaštitu potrošača građana Evropske unije bez obzira na njihovo državljanstvo? Da li te finansijske terete mogu jednako podnijeti države članice EU koje imaju snažnu i razvijenu ekonomiju kao i one slabije razvijene? Nadalje, čak i da je riječ o kvalificiranim subjektima koji su mnogoljudni i u kojima rade pravnici koji imaju ekspertizu za vođenje postupka i zastupanje, te izuzetnu ličnu motivaciju za rad i posvećenost, postavlja se pitanje finansiranja svih tih postupaka. Da li će zastupnici biti dodatno plaćeni za svoj rad koji će vrlo često biti veći od njihovog uobičajenog u organizaciji u kojoj rade? I da li će kvalificirani subjekti moći podnijeti da zadrže sve zaposlene u periodima kada nema aktivnih postupaka kolektivne zaštite, odnosno kako će ih uspjeti mobilizirati onda kada njihov rad zatreba? S tim u vezi je i činjenica da je neizvjesno kako će na stavku budžeta koja predviđa finansiranje predstavničkih subjekata, a samim tim i na zaštitu potrošača, utjecati politička previranja u smislu zavisnosti od vladajućih struktura i njihovih programskih opredjeljenja, te je nemoguće tvrditi da će sredstva za nesmetan rad kvalificiranih subjekata biti garantovana uvijek, čak i onda kada vlasti ne budu u fokusu potrošači i ostvarivanje prava na pristup sudu.

Prijedlog Direktive ne rješava pitanje finansiranja postupaka kolektivne zaštite. Član 15. predviđa da ne bi trebalo da nedostatak sredstava bude razlog zbog kojeg kvalificirani subjekti ne pokreću postupke kolektivne zaštite, te da bi trebalo da države preduzmu određene mjere, u smislu na primjer snižavanja sudskih i administrativnih taksi. Ali istovremeno tačka 39. Preambule predviđa da države članice ne mogu biti obavezane na finansiranje udružnih tužbi. Član 15. tačka $1 \mathrm{~b}$ čak predviđa da će države članice moći uspostaviti pravila koja kvalificiranim subjektima omogućavaju da zahtijevaju skromne članarine ili slične naknade za učešće od onih potrošača koji su izrazili volju da ih kvalificirani subjekat zastupa u određenom postupku kolektivne zaštite, pri čemu „skromnost“ članarine nema nikakvo dodatno određenje i uopšte nije jasno kako će se taj iznos utvrđivati. Prema tome svi naprijed istaknuti potencijalni izazovi ostaju pod znakom pitanja.

European Law Institute je još 2014. godine u svom Izvještaju o kolektivnoj zaštiti naglasio da kvalificirani subjekti moraju biti nezavisni od države u pogledu finansiranja. Ne samo da je ova nezavisnost važna zbog konstantnog budžetskog pritiska kojem su države izložene i uglavnom nedovoljno sredstava, nego i zbog toga što se javne agencije ili ustanove mogu pojaviti kao tužena stranka u postupku. ${ }^{40} \mathrm{Na}$ taj način država može biti suočena sa sukobom interesa u odlučivanju o dostupnim sredstvima za postupak u toku ili za neke buduće postupke. ${ }^{41}$

40 „Trgovcem“ se smatra svaka fizička ili pravna osoba, neovisno o tome je li u privatnom ili javnom vlasništvu, koja djeluje, uključujući i preko drugih osoba koje djeluju u njeno ime ili za njen račun, u svrhe povezane sa svojom trgovačkom, poslovnom, obrtničkom ili profesionalnom djelatnošću. Član 3, stav (2) Prijedloga Direktive.

41 Statement of the European Law Institute on Collective Redress and Competition Damages Claims, 2014, (https://www.europeanlawinstitute.eu/fileadmin/user_upload/p_eli/Publica- 
Neizbježno je da pravila o finansiranju postupka stvaraju stimulus koji ili podstiče ili sputava izvršenje. ${ }^{42}$ Evropski zakonodavac se, međutim, želio distancirati od svega što podsjeća na američki sistem kolektivne zaštite pozivajući se najčešće na neetičnost visokih iznosa naknada koje advokati ostvaruju u Sjedinjenim Američkim Državama, te nepovjerenje koje zastupani imaju prema advokatima upravo stoga što sumnjaju da advokati sklapaju nagodbe koje primarno njima odgovaraju, dok su interesi zastupanih u drugom planu. Međutim, problem nepovjerenja zastupanih prema advokatu ili advokatima koji vode postupak proizlazi iz činjenice što se radi o velikom broju tužilaca, a ne iz primjenjivog režima naknada. Također je važno naglasiti da je u postupcima kolektivne zaštite, bez obzira u kojoj su formi, neizvodivo da svaki tužilac vrši optimalnu kontrolu nad advokatom. ${ }^{43}$ To je pitanje koje će biti potrebno da i države članice riješe svaka za sebe prilikom reguliranja postupka kolektivne zaštite. Unatoč svemu navedenom, evropski zakonodavac se opredijelio za isključenje mogućnosti privatnim advokatima da imaju aktivnu legitimaciju, iako na taj način, prema analizi trenutnog stanja, rizikuje naprijed navedene izazove za ostvarivanje efikasne i efektivne zaštite. ${ }^{44}$

\subsection{KOLEKTIVNA ZAŠTITA U FUNKCIJI POBOLJŠANJA PRISTUPA PRAVDI}

Jedan od ciljeva koji Evropska unija želi ostvariti usvajanjem Prijedloga Direktive je i unaprjeđenje ostvarivanja prava na pristup sudu od strane potrošača, odnosno generalno poboljšanje pristupa pravdi. Jedinstveno poimanje pristupa pravdi ne postoji, što je i razumljivo imajući u vidu koliko je slojevit sam pojam pravde. ${ }^{45}$ Ipak, Agencija Evropske unije za osnovna prava, iako potvrdivši da ovaj izraz ne može biti definiran na jedinstven način, izdvojila je pet stubova

tions/S-5-2014_Statement_on_Collective_Redress_and_Competition_Damages_Claims.pdf, 2. 10. 2020).

42 Coffee Jr, J.C., 1986. Understanding the Plaintiff's Attorney: The Implications of Economic Theory for Private Enforcement of Law Through Class and Derivative Actions, Columbia Law Review, 86, p. 669.

43 Tzankova, I. N., 2012, Funding of Mass Disputes: Lessons from the Netherlands, Journal of Law, Economics \& Policy, 8(3), p. 555.

44 Issacharoff i Miller smatraju da će kulturološka odbojnost prema novcu i zaradi, odnosno očigledno odbijanje realnosti prema kojoj je pravna zaštita poduzetnička aktivnost, dovesti do toga da će reforme u Evropi ostati bez potrebnih nosilaca implementacije. Issacharoff, S., Miller, G. P., 2009, Will Aggregate Litigation Come to Europe, Vanderbilt Law Review, Vol. 62, p. 181.

45 Ne postoji jedinstvena definicija pojma pravde. O različitim shvatanjima ovog koncepta vidjeti: Wrbka, S. European Consumer Access to Justice Revisited, Cambridge University Press, 2015, pp. 5-25, te Storskrubb, E., Ziller, J., Access to Justice in European Comparative Law, u: Francioni, F. (ed.), 2007, Access to Justice as a Human Right, Oxford University Press, pp. 178-188. Storskrubb i Ziller navode da pravda obuhvata tri kategorije: a) pristup pravosudnoj pravdi, odnosno izvršavanje prava i prepreke u ostvarivanju pravne pomoći; b) pristup mehanizmu ostvarivanja pravde države blagostanja (engl. welfare state); i c) 'pristup pravdi sa velikim P' (ovo poimanje pravde će se na njemačkom jeziku shvatiti kao die Gerechtigkeit prije nego die Justiz). Upravo ovaj treći koncept predstavlja shvatanje pravde dovoljno sveo- 
na kojima počiva pristup pravdi. To su: 1) pravo na efikasan pristup tijelu za rješavanje sporova; 2) pravo na fer postupak; 3) pravo na pravovremeno rješavanje spora; 4) pravo na adekvatno obeštećenje; 5) principi efikasnosti i efektivnosti. ${ }^{46}$ Kroz sve ove elemente isprepleteno je pravo na pravičan postupak koje je garantirano Evropskom konvencijom o ljudskim pravima i osnovnim slobodama, što potvrđuje njegov značaj i poziciju kao jednog od ideala društva i pravne države. Kroz olakšanje pristupa pravdi, utjecalo bi se i na izjednačavanje položaja stranaka. Naime, često su na strani oštećenih oni koji su u (finansijski, ali ne samo finansijski) slabijem položaju. U takvim situacijama zbog brojnosti povrijeđenih $\mathrm{s}$ jedne strane, te zbog protupravno ostvarene koristi s druge strane, uspostavlja se disbalans u kome oni koji su svakako moćniji ostvaruju još više dobiti, dok oni koji to nisu bivaju indirektno lišeni mogućnosti da ostvare svoje pravo. ${ }^{47}$ Kolektivna pravna zaštita ima potencijal da postojeće odnose moći promijeni tako da olakša pristup zaštiti prava, a time i pristup pravdi, licima koja su u startu u nepovoljnijoj poziciji, te da na taj način osigura zaštitu slabije strane i uspostavljanje procesne jednakosti. ${ }^{48}$ Pri tome se kolektivne tužbe ne smatraju optimizacijom individualnih interesa, već ostvarivanjem kolektivne pravde koja pojedincima daje barem mogućnost postizanja odštete, najčešće u slučajevima u kojima ne bi mogli prevladati na pojedinačnom nivou. ${ }^{49}$ Pored kompenzatorne uloge, kolektivna zaštita bi trebalo da ima i ulogu sprečavanja daljeg štetnog postupanja, kao i preventivnog djelovanja na buduća slična kršenja prava. Kolektivnom zaštitom bi se dao značaj svakoj pojedinoj pretrpljenoj šteti ili povredi prava bez obzira koliko mali po vrijednosti bili. Međutim da li će do osnaživanja potrošača doći i na ovaj način, zavisi prvenstveno od efikasnosti kolektivne zaštite u praksi, jer privrednik može procijeniti da mu je jeftinije namiriti štetu nego promijeniti protupravno ponašanje. Kompenzacija i odvraćanje su ciljevi ove zaštite, ali izražavaju različite vrijednosti. Dok je kompenzacija fokusirana na potrošača, odnosno na ideju da potrošač treba dobiti ono za šta je platio, odvraćanje se fokusira na proizvođače sa ciljem da ih motivira da se radije ponašaju na dobar nego na loš način. ${ }^{50}$ Svrha Direktive je pokretanje udružnih tužbi za zaštitu kolektivnih interesa potrošača. Pri tome kolektivni interes nije prosti zbir individualnih interesa, nego uključuje i javni interes da ovim povrijeđenim individualnim bude

buhvatno da se odnosi ne samo na pravo koje primjenjuju pravosudni organi nego i na šire poimanje pravednosti i pravičnosti u društvu.

46 European Union Agency for Fundamental Rights, Access to Justice in Europe: An Overview of Challenges and Opportunities, 2010, p. 14, (https://fra.europa.eu/sites/default/files/ fra_uploads/1520-report-access-to-justice_EN.pdf, 6. 10. 2020).

47 Hondius, E., Public and Private Enforcement in Consumer Protection - A Dutch Perspective, u: Cafaggi, F., Micklitz, H.-W., (eds.), 2009, p. 238.

48 Einhaus ovo naziva političkom dimenzijom kolektivne zaštite, ali istovremeno naglašava da se uspostavljanju materijalne jednakosti može samo težiti, a u stvarnosti je nedostižna u potpunosti jer zavisi od prirode ljudi, te ju je nemoguće jedinstveno kvantificirati, p. 42.

49 Micklitz, H.-W., 2007, Collective Private Enforcement of Consumer Law: The Key Questions, u: Collective Enforcement of Consumer Law, Securing Compliance in Europe through Private Group Action and Public Authority Intervention, p. 17.

50 Miller, G. P., Compensation and Deterrence in Consumer Class Actions in the United States and Europe, u: Cafaggi, F., Micklitz, H.-W., (eds.), 2009, p. 264. 
obezbijeđena zaštita, a posebno zbog toga što se radi o zaštiti slabije strane u sporu, pa se time želi očuvati i povjerenje u pravni poredak svih učesnika u pravnom prometu. Vrlo često se postupci kolektivne zaštite označavaju i kao parnice od javnog interesa, a s obzirom na to da imaju element kreiranja politike, koji se čak može približiti i socijalnom inženjeringu. ${ }^{51}$ Evropa želi kolektivno pravno sredstvo kao sredstvo za osiguravanje naknade oštećenim i kao sredstvo za odvraćanje od neprimjerenog ponašanja i nezakonite i nepoštene poslovne prakse, ali pod uslovom da to bude ostvareno bez mogućnosti ostvarivanja profita. Ako zbog mogućih izazova adresiranih u prethodnim dijelovima postoji mogućnost da kvalificirani subjekti nisu optimalno rješenje, onda postoji rizik da pozitivni efekti kolektivne zaštite budu samo polovično iskorišteni, kao i da javni interes zaštite pravnog poretka ne bude u potpunosti ostvaren.

\subsection{MOGUĆA RJEŠENJA}

Ukoliko zastupnik u određenom komplikovanom i masovnom slučaju ostvarivanja zaštite prava nema ličnog i/ili finansijskog interesa, niti motiva, nego radi za standardnu platu u organizaciji koja je kvalificirani subjekat, teško se može očekivati naročita posvećenost i angažman, a koji su za zastupanje u masovnim parnicama neophodni imajući u vidu brojnost tužbenih zahtjeva, te detalja i pojedinosti kojima takvi slučajevi obiluju. S druge strane, advokati u class action sistemu su upravo ličnim profitom motivirani na kreativno vođenje postupka i ostvarivanje uspjeha u sporu. Čak i kad bi se uzeli kao opravdani prigovori da se neproporcionalno i neetički bogate $\mathrm{u}$ takvim slučajevima, iako zapravo naplaćuju svoje znanje, iskustvo i sposobnost vođenja postupka u pravnom sistemu koji se oslanja na privatno izvršenje i koji im takvo naplaćivanje dozvoljava, i dalje smatramo da bi davanje mogućnosti angažmana advokata preko kvalificiranih subjekata bilo izuzetno korisno za uspjeh mehanizama kolektivne zaštite i u Evropskoj uniji. Naime, privatni advokati ne znače nužno zloupotrebe. Oni su na velikom udaru kritika jer ih se izjednačava sa sistemom u kojem djeluju, a koji je potpuno različit od evropskih pravnih sistema. Međutim, omogućavanje advokatima, koji potiču iz evropske pravne kulture i djeluju u njoj, da budu angažirani na predmetima kolektivne zaštite, koji se odvijaju po nacionalnim pravilima država članica, ne znači i preuzimanje svih karakteristika postupka class actions. Problemi zbog kojih su kontinentalni pravnici isključivi u pogledu privatnih advokata se mogu riješiti u evropskim pravnim sistemima tako da se zarada prilagodi vrijednostima koje preovladavaju u društvenopolitičkom uređenju država Evropske unije, a da se istovremeno iskoristi sposobnost advokata da uspješno i efikasno vode postupke kolektivne zaštite. Ostvarivanje profita na ime odrađenog posla zastupanja stranaka u postupku kolektivne zaštite, koji znači i ostvarivanje javnog interesa zaštite prava slabije strane i generalno poboljšanje pristupa pravdi, nisu i ne moraju biti međusobno isključivi.

Moguća opcija prilagođavanja evropskom pravnom sistemu bi bila uvođenje posebnog vida oporezivanja profita ostvarenog u postupcima kolektivne zaštite

Uzelac, A., 2014, p 65. 
koji bi bio proporcionalan zaradi. Ovaj porez bi mogao imati čak i različitu stopu oporezivanja u zavisnosti od visine ostvarene zarade. Na taj bi način i dalje bio zadržan i iskorišten motiv kompetentnih i poduzetnih advokata za uspješno vođenje spora i zastupanje masovno oštećenih, te u konačnici i ostvarivanje njihove zarade, ali bi se osiguralo da ne dođe do neracionalnog bogaćenja i zloupotreba, te bi država i dalje zadržala određenu ulogu regulatora. Odnosno, ovo bi bio put da takva sredstva, ako i budu naplaćena od privrednika koji je protupravno postupao, budu kroz porez ili neki drugi vid javne naplate dijelom usmjerena u funkcioniranje kvalificiranih tijela ili formiranje fonda za podršku kolektivnoj zaštiti potrošača, odnosno da budu vraćena i ponovo uložena za javni interes. $\mathrm{Na}$ taj način bi se doprinijelo i ujednačavanju procesnih sredstava, te većem povjerenju potrošača, ali i njihovom čuvanju od bilo kakvih dodatnih troškova, jer ipak nisu u jednakom položaju u odnosu na velike korporacije, a koje su često u ulozi štetnika.

Imajući u vidu da se kod predmetnog Prijedloga Direktive radi o direktivi minimalne harmonizacije, države članice su slobodne obezbijediti i viši nivo zaštite od onog koji garantuje Direktiva. ${ }^{52}$ Ako se viši nivo zaštite može obezbijediti uz angažovanje advokata, čak i preko kvalificiranih subjekata, i uz uvažavanje opredjeljenja Evropske unije da onemogući zloupotrebu sudskih postupaka, bilo bi uputno razmisliti o načinu transpozicije navedenog Prijedloga Direktive u nacionalne pravne sisteme u segmentu koji se odnosi na aktivnu legitimaciju onda kada Direktiva stupi na snagu.

\section{ZAKLJUČAK}

Kvalitet prava se ne može zadržati samo na kvalitetnom materijalnom pravu. Materijalno pravo mora biti lako shvatljivo i primjenjivo njegovom adresatu, ali isto tako mora biti lako provodivo. Materijalna pravila nisu dovoljna za tvrdnju da je određena oblast regulirana i uređena. Ona moraju imati garant svoje provodivosti, a to se osigurava kroz procesna pravila. I sama procesna pravila imaju snagu onda kada su primjenjiva u praksi. Upravo sve navedeno Evropska unija želi postići kroz sistem kolektivne zaštite. Zamišljeni mehanizam ostvarivanja zaštite putem udružnih tužbi sadržan u Prijedlogu Direktive u svom temelju sadrži opredjeljenje obaveznog izbjegavanja mogućnosti zloupotrebe postupaka zaštite, zbog čega se želi onemogućiti učešće advokata u ovim postupcima, jer se oni smatraju generatorom svih zloupotreba koje se dešavaju u američkom class actions sistemu. Ipak, evropski zakonodavac želi pozitivne efekte tog sistema na zaštitu prava potrošača u potpuno drugačijem pravnom sistemu. Međutim, dodjeljivanje ovlaštenja za pokretanje postupaka kolektivne zaštite isključivo kvalificiranim subjektima i oslanjanje samo na njihov kapacitet sa sobom nosi izazove u pogledu kompetencija, te kadrovskih i operativnih mogućnosti tih subjekata. Posebno je problematično finansiranje rada kvalificiranih subjekata. Potrošači nisu spremni snositi troškove postupka, te je temeljna pretpostavka da su tužioci u postupci-

52 Rabe, H. J., 2010, Kollektivklagen. Zeitschrift für europäisches Privatrecht, (1), s. 3. 
ma kolektivne zaštite opskrbljeni adekvatnim fondovima. Postupcima kolektivne zaštite je cilj poštediti potrošače velikih procesnih troškova na individualnom nivou. Ako načini finansiranja nisu precizirani i osigurani, a prema trenutnom Prijedlogu Direktive države članice nisu dužne finansirati udružne tužbe, primjena i efikasnost kolektivne zaštite bi mogla biti upitna. Svojim izborom načina transpozicije u nacionalno pravo države članice će se opredijeliti da li podstiču ili ne razvoj i primjenu mehanizama kolektivne zaštite u praksi. Pri tome i evropski i nacionalni zakonodavci, zajedno sa ostalim granama vlasti, trebalo bi da imaju u vidu da pravo mora imati mogućnost efikasnog provođenja u praksi, a što je u konačnici ili na početku zapravo i cilj ovog legislativnog poduhvata Unije.

\section{LITERATURA}

1. Cafaggi, F., Micklitz, H.-W., 2008, Administrative and Judicial Enforcement in Consumer Protection: The Way Forward, EUI Working Papers LAW, No. 2008/29.

2. Coffee Jr, J. C., 1986, Understanding the Plaintiff's Attorney: The Implications of Economic Theory for Private Enforcement of Law Through Class and Derivative Actions, Columbia Law Review, 86.

3. Davies, J., 2012, How Well Placed Is the Optimism Surrounding the New ADR/ODR Proposals?, Zeitschrift für Europäisches Unternehmens- und Verbraucherrecht, 2.

4. Einhaus, S., 2008, Kollektiver Rechtsschutz im englischen und deutschen Zivilprozessrecht, Duncker \& Humblot.

5. Hodges, C., 2001, Multi-Party Actions: European Approach, Duke Journal of Comparative \& International Law, 11(2).

6. Hodges, C., 2014, Collective Redress: A Breakthrough or a Damp Sqibb?, Journal on Consumer Policy, 37.

7. Hondius, E., Public and Private Enforcement in Consumer Protection - A Dutch Perspective, u: Cafaggi, F., Micklitz, H.-W. (ed.), 2009, New Frontiers of Consumer Protection - The Interplay between Private and Public Enforcement, Intersentia.

8. Issacharoff, S., Miller, G. P., 2009, Will Aggregate Litigation Come to Europe, Vanderbilt Law Review, Vol. 62.

9. Issacharoff, S., Samuel, I., The Institutional Dimension of Consumer Protection, u: Cafaggi, F., Micklitz, H.-W. (ed.), 2009, New Frontiers of Consumer Protection - The Interplay between Private and Public Enforcement, Intersentia.

10. Jeretina, U., Uzelac, A., 2014, Alternative Dispute Resoultion for Consumer Cases: Are Divergences an Obstacle to Effective Access to Justice?, Mednarodna revija za javno upravo, XII (4).

11. Micklitz, H.-W., 2007, Collective Private Enforcement of Consumer Law: The Key Questions, Collective Enforcement of Consumer Law, Securing Compliance in Europe through Private Group Action and Public Authority Intervention.

12. Miller, G. P., Compensation and Deterrence in Consumer Class Actions in the United States and Europe, u: Cafaggi, F., Micklitz, H.-W. (eds.), 2009, New Frontiers of Consumer Protection - The Interplay between Private and Public Enforcement, Intersentia.

13. Poretti, P., 2010, Collective Redress in the European Union - Current Issues and Future Outlook, EU and Comparative Law Issues and Challenges Series, 3. 
14. Povlakić, M., Mezetović Međić, S., 2016, Kolektivna zaštita (potrošača) prema pravu Evropske unije i pravu Bosne i Hercegovine, Aktualnosti građanskog i trgovačkog zakonodavstva i pravne prakse, 14.

15. Rabe, H. J. (2010), Kollektivklagen, Zeitschrift für europäisches Privatrecht, 1.

16. Smith, V., 2011, Towards a Coherent European Approach to Collective Redress: More Questions than Answers, Business Law Review, 32.

17. Stadler, A., Foreword, u: Lein, E., Fairgrieve, D., Otero Crespo, M., Smith, V. (eds.), 2015, Collective Redress in Europe: Why and How?, British Institute of International and Comparative Law.

18. Stier, B., 2016, The Promise and Peril of Media and Culture: The Toyota Unintended Acceleration Litigation and the Gulf Coast Claims Facility in the United States, u: Class Actions in Context, Edward Elgar Publishing.

19. Stier, B., Tzankova, I., 2016, The Culture of Collective Litigation: A Comparative Analysis, u: Class Actions in Context, Edward Elgar Publishing.

20. Storskrubb, E., Ziller, J., Access to Justice in European Comparative Law, u: Francioni, F. (ed.), 2007, Access to Justice as a Human Right, Oxford University Press.

21. Taruffo, M., 2001, Some Remarks on Group Litigation in Comparative Perspective, Duke Journal of Comparative \& International Law, 11(2).

22. Tzankova, I. N., 2012, Funding of Mass Disputes: Lessons from the Netherlands, Journal of Law, Economics \& Policy, 8(3).

23. Tzankova, I., 2016, Collective Redress in Vie d'Or: A reflection on a European Cultural Phenomenon, u: Class Actions in Context, Edward Elgar Publishing.

24. Uzelac, A., 2014, Why No Class Actions in Europe? A View from the Side of Dysfunctional Justice Systems, Multi-Party Redress Mechanisms in Europe: Squeking Mice?

25. Voet, S., 2014, European Collective Redress: A Status Quaestionis, International Journal of Procedural Law, 4.

26. Weatherill, S., 2012, Maximum versus Minimum Harmonization: Choosing between Unity and Diversity in the Search for the Soul of the Internal Market, From Single Market to Economic Union: Essays in Memory of John A. Usher.

27. Wrbka, S., 2015, European Consumer Access to Justice Revisited, Cambridge University Press.

\section{PROPISI}

1. Green Paper On Consumer Collective Redress COM (2008) 794 final od 27. 11. 2008. godine.

2. Preporuka 2013/396/EU od 11. 6. 2013. o zajedničkim načelima za kolektivne tužbe na propuštanje i tužbe radi naknade štete u državama članicama kod povrede prava zajamčenih zakonodavstvom Unije.

3. Prijedlog Direktive o udružnim tužbama za zaštitu kolektivnih interesa potrošača i stavljanju izvan snage Direktive 2009/22/EZ COM(2018) 184 final od 11. 4. 2018.

4. Regulation (Eu) No 254/2014 of the European Parliament and of the Council of 26 February 2014 on a multiannual consumer programme for the years 2014-20 and repealing Decision No 1926/2006/EC.

5. Rezolucija Evropskog parlamenta Towards a coherent European approach to collective redress (2011/2089(INI)) od 2. 2. 2012. 


\title{
IZVORI SA INTERNETA
}

1. Consumer vulnerability across key markets in the European Union, London Economics, VVA Consulting i Ipsos Mori consortium, Evropska komisija, januar 2016, (http://ec.europa.eu/consumers/consumer_evidence/market_studies/docs/vulnerable_consumers_approved_27_01_2016_en.pdf, 5. 10.2020).

2. Europe 2020, a strategy for smart, sustainable and inclusive growth, COM (2010) 2020 final, (https://eur-lex.europa.eu/legal-content/EN/TXT/PDF/?uri=CELEX:5201 0DC2020\&from=en, 6. 10. 2020).

3. European Law Institute Statement on Collective Redress and Competition Damages Claims, 2014, (https://www.europeanlawinstitute.eu/fileadmin/user_upload/p_eli/ Publications/S-5-2014_Statement_on_Collective_Redress_and_Competition_Damages_Claims.pdf, 2. 10.2020).

\section{LEGAL STANDING IN COLLECTIVE REDRESS PROCEEDINGS - IS THERE ROOM FOR PRIVATE ATTORNEYS?}

\author{
Selma Mezetović Međić
}

SUMMARY

The issue of standing in collective redress proceedings is a matter of greatest divergence between continental and common law systems. At the same time, it is an issue that almost completely united European lawyers in the view that collective redress procedures in the European Union must not be entrusted to private lawyers as is the case in the United States. This paper seeks to provide a critical overview of the debate on whether private attorneys should have any role in collective redress proceedings. It will do so by, firstly, examining potential challenges in the work of qualified entities primarily when it comes to their capacity, motivation and financial resources; secondly, by bringing it in connection to the decision if the role that collective redress should be compensatory or deterrent; and finally, by addressing the alleged mutual exclusiveness of profit-oriented work and attention to public interest. The article proposes that there is room for reconsidering the current negative exclusive attitude towards private attorneys in light of the main purpose of the collective actions which is establishing robust, efficient and effective enforcement system.

Key words: standing, collective redress, qualified entities, consumer protection, private attorney, abusive litigation, minimum harmonisation. 